\title{
IMPROVING VOCABULARY USING TGT (TEAMS GAMES TOURNAMENT) METHOD
}

\author{
Hilyah Rihanah ${ }^{1}$, Sudiyono ${ }^{2}$ \\ ${ }^{1}$ IKIP Siliwangi \\ ${ }^{2}$ IKIP Siliwangi \\ ${ }^{1}$ rihanahhilyah29@ student.ikipsiliwangi.ac.id, ${ }^{2}$ sudiyonostkipslw@gmail.com
}

\begin{abstract}
This study aims to improve vocabulary through Team Game Tournament Techniques in class IX students of one of the junior high schools conceived. The sample of this research was 32 students. The method used in this research was action research applied in two cycles. Then the data was collected by using multiple choice tests (pre-test and post-test). The results that the TGT method can be improved vocabulary students, it was showed from the table score that increased from the mean score of pre-test, post-test cycle 1 and post-test cycle 2 . The mean score of pre-test was 55.94, the mean score of the pretest cycle was 74.37 and the mean score of the post-test cycle 280.31 .it is assumed that the TGT method is effective to improve vocabulary students and then the use of the TGT technique makes students more motivated.
\end{abstract}

Keywords: Vocabulary, TGT (Teams Games Tournament), CAR

\section{INTRODUCTION}

English is one of the languages that must be mastered by every individual because english has become an international language. In this globalization era, every individual must have english language skills because english is very important language both in the world of education and the world of work. English has become a common subject and must be taught in every department. That is, english lessons are given to all students at the school or university level. The problem we often encounter is the lack of vocabulary in english. In some cases in junior high school is low in their vocabulary. When we want to speak English, we can not speak without vocabulary. When we want to communicate with people by written, vocabulary have to be involved. When we want to hear people speaking in English, of course we hear spoken vocabulary. Vocabulary is central to learning and teaching of a second language. It means vocabulary is important for us without having vocabulary, students have difficulties to learn English.

From the above problem, english teacher plays an important role in improving students' vocabulary mastery. They should use appropriate method that can make students' interesting and fun with the materials. Teachers must have appropriate method that suitable with their students' which can facilitate the students to understand the vocabulary given easily.

There are various teaching methods that can be done to improve vocabulary student's such as Jigsaw, Clustering, Wordwall, TPS (Think Pair Share), TGT (Team Game Tournament) and etc. All these method are useful to improve their vocabulary. The researcher used TGT (Team Game Tournament) to solve this problem. This article used CAR (Classroom Action Research) approach to determine the ability of students. CAR (Classroom Action Research) is action research to improve the quality of learning in the classroom. Teams-Games-Tournaments were originally developed by David DeVries and Keith Edwards at the University of Johns Hopkins. 
It uses the same teacher presentations and team work as in STAD, but replaces the quizzes with weekly tournaments, in which students play academic games with members of other teams to contribute points to their team scores (Sunarti, Puspita \& Halim , 2019). In this model the class is divided into small groups consisting of 3 to 5 students with different levels of ability, gender, and ethnic background, then students will work together in small groups. TGT is a learning model based on Cooperative Learning which shows postive interdependency, face to face interaction, individual responsibility, communication between members in group and process evaluation in group (Ristanto, Zubaidah, Amin \& Rohman, 2018) as cited in (Pradhita Yudhi Astri et al., 2018)

Team-Games-Tournament technique Kiyikkaya, Iseri \& Vurkaya (2010) suggested that games will make learning more effective than using traditional learning, especially to improve the learning,active participation, and student concentration (Pradhita Yudhi Astri et al., 2018). Furthermore, that the positive interdependence created by groups helps to improve the motivation in the group. Team games Tournament is a type of cooperative learning resulting from the development types STAD (Student Teams-Achievement Divisions), where students learn in small groups with a major component in the form of classroom presentations, team discussions, quizzes, scores of individual advancement, and recognition of the team. While the difference of the two types is the existence of academic game on the type TGT, so that they did not feel bored in teaching learning process and the student's feel enthustiastics to answer the question which were delivered through games in the team competition.

\section{Vocabulary}

Vocabulary is a collection of words that are part of a particular language and used to arrange sentences. Vocabulary learning is central to language acquisition, whether the language is first, second, or foreign ( Murcia, 2001: 285 as cited in Parmawati, 2019). According to Nation (1990: 02) as cited in Tarigan (2018) vocabulary is very important element in language learning for both learners and teachers. It means that mastery is ability to use one's knowledge (Nasution, 2018). Furthermore without vocabulary we can not understand communicate in english. Hanson and Padua (2011, p.5) as cited in Noviyanti \& Bahri (2019) define that the words people use when communicating in oral or written reference to the vocabulary.

\section{Team Game Tournament}

Team Game Tournament is where the students play games with members of other teams to add points to their team scores (Slavin 2005: 256) as cited in Gani (2019). A weakness that occurs in the TGT model is a learning process that can lead to saturation (Jura et al., 2018 in Zaitun \& Izzah (2019). This method is a method that used widely in the field of formal education and it was effective to improve outcomes learning of student (Sari et al., 2019). There are steps used TGT in teaching and learning process :

1. Class presentation

The teacher presents the material to students

2. Team

The group usually consists of four to five students. The function of the group is to further explore the material with group.

3. Game

The game consists of questions which content is relevant. That is designed to test the students knowledge gained from presentation in class and the implementation of teamwork.

4. Tournament

Tournament is a structure where the game takes place.

5. Team recognise 
The team will get award if the winner earns one point for his/her team regardless of how many questions they answered correctly or how difficult the questions were

\section{METHOD}

This method used in the research is PTK is action research conducted in class with the aim of improving or improving the quality of learning practices (Arikunto et al., 2008: 58) as cited in Sindrayuni et al (2020).

There are four steps of Classroom Action Research there are :

1. Planning

2. Action

In this phase the researcher prepared material for explanation session.

The plan is applied TGT in teaching learning process.

3. Observation

The researcher observed the student's during teaching learning process and the

4. Reflection researcher know whether or not TGT method can improve their skill.

At this point the researcher reflect, evaluated and describe the effects of the observation of implementing TGT method whether or not can improving their skill. Statistical technique is used to find the mean score. The formula to find the mean as stated by Ngadiso (2013: 5-7) (Parmawati, 2019) is follows :

$$
\begin{aligned}
& M=\frac{\sum X}{N} \\
& M= \text { Mean score } \\
& \sum X=\text { Total Score } \\
& N=\text { Total students }
\end{aligned}
$$

If the mean score of students increases, the students vocabulary increases to.

The subject study was one of junior high school in Bandung on the first semester 2019/2020. There are 6 class of ninth grade. The researcher took the sample is IX A. The total of student's are 32 students with specification 16 Male and 16 Female.

\section{RESULTS AND DISCUSSION}

\section{Results}

Here is the report of concerning the data by pretest and posttest (cycle 1 and cycle 2). The following table shows score of the test :

Table. Score of students

\begin{tabular}{cccccc}
\hline No. & Name & Gender & Pre-test & $\begin{array}{c}\text { Post-test } \\
\text { Cycle 1 }\end{array}$ & $\begin{array}{c}\text { Post-test } \\
\text { Cycle 2 }\end{array}$ \\
\hline 1 & Student 1 & M & 55 & 75 & 80 \\
2 & Student 2 & F & 60 & 75 & 85 \\
3 & Student 3 & F & 65 & 80 & 90 \\
4 & Student 4 & M & 60 & 75 & 75 \\
5 & Student 5 & F & 55 & 70 & 80 \\
6 & Student 6 & M & 65 & 75 & 80 \\
7 & Student 7 & F & 70 & 80 & 85 \\
8 & Student 8 & F & 60 & 70 & 80
\end{tabular}




\begin{tabular}{cccccc}
9 & Student 9 & F & 50 & 70 & 75 \\
10 & Student 10 & M & 50 & 75 & 80 \\
11 & Student 11 & M & 50 & 75 & 75 \\
12 & Student 12 & F & 45 & 80 & 80 \\
13 & Student 13 & M & 45 & 75 & 80 \\
14 & Student 14 & M & 45 & 70 & 85 \\
15 & Student 15 & F & 60 & 75 & 75 \\
16 & Student 16 & M & 65 & 70 & 75 \\
17 & Student 17 & M & 55 & 75 & 75 \\
18 & Student 18 & M & 50 & 75 & 85 \\
19 & Student 19 & F & 45 & 70 & 85 \\
20 & Student 20 & F & 50 & 70 & 70 \\
21 & Student 21 & F & 45 & 75 & 80 \\
22 & Student 22 & M & 50 & 80 & 75 \\
23 & Student 23 & F & 45 & 75 & 75 \\
24 & Student 24 & M & 55 & 75 & 75 \\
25 & Student 25 & M & 50 & 65 & 80 \\
26 & Student 26 & F & 60 & 65 & 75 \\
27 & Student 27 & F & 65 & 85 & 95 \\
28 & Student 28 & F & 65 & 70 & 80 \\
29 & Student 29 & F & 60 & 75 & 80 \\
30 & Student 30 & M & 65 & 70 & 80 \\
31 & Student 31 & M & 65 & 85 & 90 \\
32 & Student 32 & M & 65 & 80 & 90 \\
& & & 55.94 & 74.37 & 80.31 \\
\hline & Mean & & & \\
\hline
\end{tabular}

Based on the table above we can see the score minimum of pre-test was 45 and the score maximum was 70 . Then in cycle 1 the score minimum of post-test was 65 and the score maximum of post-test was 85 . And then in cycle 2 the score minimum of score was 70 and the score maximum of post-test 95 . It was known that the score minimum and maximum of posttest in cycle 1 and cycle 2 higher than pre-test.

\section{Discussion}

\section{Cycle 1}

The research did at YPKKP Junior high school in 34 students of VIII A on 11 february 2020. The first steps of CAR is planning. In this stage, the researcher was conducted as a real action. The aim was to know what the problem of the students in learning English lesson especially in vocabulary. The researcher design the lesson plan from syllabus which is consulted with English teacher, creating the topic able with students need and preparing the material that will be used in the class during research . The researcher teach vocabulary in narrative text using TGT method. The second steps is acting. In this step, the researcher came to the class four times. The first was used for operate pre-test which subsited of 10 items. The same thing went to fourth encounter was used for post-test which subsisted of the same as pre-test. The third observing. The researcher observed the teaching learning process when she did implemented the technique. In observation the researcher walking around class and did sight seeing of the students activity. And the last reflection. The researcher analyze about the result of the implementation of TGT method to improve vocabulary students. If the classroom action research target could not be achieved, move to cycle 2, but if the students test result has 
completed the criterion of success in this research the cycle would stop. It started from pre-test. The students had read of material about narrative text that would be delivered. But the students get a bad grades. The value of KKM determine is 70,00 and the average of pre-test is 55,94 . During treatment 1 and 2 the students make a groups, one group subsisting 4-5 students. In the treatment 1 and 2 the researcher work in groups. From this treatment in cycle 1 there are positive and negative result. The positive result the student increase in score of post test in cycle 1 . And the negative some students less active in teaching learning process the students rely onother students do the work. Revisions should be made to improve the quality of their learning as well as their average value.

\section{Cycle 2}

In cycle 2 includes four steps in accordance with those contained in cycle 1 . In the planning the the researcher began with making new lesson plan with some revised part. It was aimed to get better in cycle 2 . The researcher prepare the material that has been revised previously. For revisions, researcher create a new group that is different for each students. they were given a new texts with the same theme of narrative text. The acting session includes the post-test of the previous cycle. The final step is to Reflect on the observations made will be discussed in this section. This strategy is expected to reduce the students' habits in relying on each other. The final step is to Reflect on the observations made will be discussed in this section. There are many improvements based on identification the problem, it was known that the students English vocabulary in one of junior high school of Bandung was low. It was showed from the table score above that increased from the score of pre-test, post-test in cycle 1 and post-test cycle 2 . It is assumed that TGT method is effective to improve vocabulary students.

\section{CONCLUSION}

From the results of this study it can be concluded that the application of the TGT (Team Game Tournament) method in Classroom Action Research is effective for increasing their vocabulary as seen from the increase in the average value of the pretest then postest in cycle 1 and postest cycle 2 . In pretest the average value is 55.94 then the average value postest cycle 1 is 74.37 and the average of postest cycle 2 is 80.31 . It can conclude TGT method is simple method easily to understand students. TGT method gives students motivation to learn vocabulary more effectively and easily. And then students can motivate other students in a team and help the students who are low in understanding the lesson (Salam et al, 2015) (Halim, 2019).

\section{ACKNOWLEDGMENTS}

In the name of Allah because of Him, the researcher could finish this article. Prophet Muhammad SAW who has guided us from the darkness to the lightness. This article have not been completed without support, guidance from individual and institution. Therefore, the researcher would likes to express special thanks to:

1. Hj. Sudiyono M.Pd as the advisor for their guidance and help to finish this article

2. My beloved parents and family to giving prayers and support.

3. All students of SMP YPKKP Bandung for great participations during research.

\section{REFERENCES}

Gani, H. R. A. (2019). The Use Of Team Game Tournament To Improve Students'elt Classroom Interaction And Reading Comprehension In Relation To Self-Efficacy. Jo-Elt 
(Journal Of English Language Teaching) Fakultas Pendidikan Bahasa \& Seni Prodi Pendidikan Bahasa Inggris Ikip, 6(2), 84-90.

Nasution, M. (2018, July). The Effect of Team Games Tournament (TGT) Method Toward Vocabulary Mastery at the Tenth Grade Students of Hgh School 1 Padangsidimpuan. In IOP Conference Series: Earth and Environmental Science (Vol. 175, No. 1, p. 012087).

Noviyanti, R., Bahri, S., \& Nasir, C. (2019). The Use of Think Bingo Game to Improve Students' Vocabulary Mastery. Research in English and Education Journal, 4(1), 1-8.

Parmawati, A. Using Magic Sentences Technique To Improve Students'vocabulary (Classroom Action Research In The First Semester Students Of Ikip Siliwangi Bandung).

Pradhita Yudhi Astri, T., Gunarhadi, G., \& Riyadi, R. (2018). Numbered-Board Quiz with TGT to Improve Students' Science Achievement based on Learning Motivation. International Journal of Educational Research Review, 3(4), 68-76. https://doi.org/10.24331/ijere.452982

Sari, D. M., Baddrah, S., \& Satriana, M. (2019, June). Teams Games Tournament Method in Improving Knowledge, Attitude, and Handwashing with Soap Practice on 3Th Grade Elementary School Students. In Educational Sciences International Conference (ESIC 2018). Atlantis Press.

Sindrayuni, D., Sastromiharjo, A., Mulyati, Y., \& Damaianti, V. (2020, March). Application of the Emilia Reggio Approach (Rea) Assisted by Flash Card Media to Improve the Mastery of Indonesian Vocabulary in Children Ages 5 to 6 Years. In International Conference on Elementary Education (Vol. 2, No. 1, pp. 1597-1606).

Sunarti, S., Puspita, R. H., \& Halim, A. (2019). Teams-Games-Tournament (TGT) to Teach Vocabulary of English for Specific Purpose in Increasing Students' Self-Esteem. Indonesian EFL Journal: Journal of ELT, Linguistics, and Literature, 5(1), 39-55.

Zaitun, \& Izzah, L. (2019). Classroom Action Research in Action. The 7th International Conference on Teaching English as Foreign Language (COTEFL), 3(1), 579-582. https://doi.org/10.5281/zenodo.1214958 